\title{
Special issue on Plasma Processes
}

The present issue of the European Physical Journal - Applied Physics (EPJ-AP) is dedicated to papers on Plasma Processes, covering a variety of subjects that include the study of advanced plasma sources (including micro-discharges), the characterization of plasmas (using both modeling and experimental diagnostics to analyze fundamental kinetic mechanisms and/or the structure of discharges), and the use of plasmas for surface engineering (employing etching, deposition, sputtering and multi-functional coating techniques implemented with different plasma sources, relating the properties of the processed films to the plasma conditions, and addressing also the influence of dust), keeping in mind forefront applications in the fields of micro- and nanotechnology, bio-medicine, and environment (sensors and catalytic conversion).

These subjects correspond to the list of topics covered by the International Colloquium on Plasma Processes (CIP), a biennial international conference organized under the auspices of the French Vacuum Society, which focuses on the latest developments in plasma processing science and technology. The 18th edition of this event was held in Nantes (France) from 4 to 8 July 2011, and the 26 peer-reviewed papers with this special issue correspond to a selection of different original contributions (invited, oral and poster) to the CIP11.

As Associated Editors of the EPJ-AP, and Guest Editors for this special issue, we are pleased to publish this selection of papers, constituting a well-balanced representation of the topics treated during the conference and providing a comprehensive covering of the main concerns in the field of plasma processes. We would like to thank all the authors and referees for their efforts in preparing and reviewing the manuscripts, within very strict deadlines, as well as the Editorial Office of the EPJ-AP for its helpful assistance in organizing this special issue on Plasma Processes.

Guest Editors

L.L. Alves

Instituto de Plasmas e Fusão Nuclear (IPFN)

IST, Lisbon, Portugal

Y. Ségui

Laboratoire Plasma et Conversion de l'Energie (LAPLACE)

Toulouse, France 


\section{List of papers}

18th International Colloquium on Plasma Processes (CIP 2011)

24001 L.L. Alves

Special issue on Plasma Processes

24002 S. Konstantinidis, and R. Snyders (Invited paper)

Reactive ionized physical vapor deposition of thin films

24003 N. Denisova, E. Bogans, G. Revalde, and Ja. Skudra

A study of physical processes in microplasma capillary discharges

24004 V. Guerra, K. Kutasi, P.A. Sá, and M. Lino da Silva (Invited paper)

Influence of nitrogen impurities on the formation of active species in $\mathrm{Ar}-\mathrm{O}_{2}$ plasmas

24005 M. Meziane, O. Eichwald, J.P. Sarrette, O. Ducasse, and M. Yousfi

2D simulation of active species and ozone production in a multi-tip DC air corona discharge

24006 P. Cerny, S. Novak, R. Hrach, and V. Hrachova

Computational study of sheath structure in chemically active plasmas

24007 D. Curreli

Transition from edge-localized to center-localized power deposition in helicon discharges

24008 K. Gadonna, O. Leroy, T. Silva, P. Leprince, C. Boisse-Laporte, and L.L. Alves

Hydrodynamic study of a microwave plasma torch

24009 A. Nikiforov, L. Li, Q. Xiong, C. Leys, and X.P. Lu

LIF spectroscopy of $\mathrm{OH}$ radicals in a micro-flow DC discharge in Ar and He with a liquid electrode

24010 I. Zymak, P. Jusko, Š. Roučka, R. Plašil, P. Rubovič, D. Gerlich, and J. Glosík

Ternary association of $\mathrm{H}^{+}$ion with $\mathrm{H}_{2}$ at $11 \mathrm{~K}$, experimental study

24011 T. Kotrík, P. Dohnal, P. Rubovič, R. Plašil, Š. Roučka, S. Opanasiuk, and J. Glosík

Cryo-FALP study of collisional-radiative recombination of $\mathrm{Ar}^{+}$ions at $40-200 \mathrm{~K}$

24012 G. Kokkoris (Invited paper)

Towards control of plasma-induced surface roughness: simultaneous to plasma etching deposition

24013 A. Valovič, J. Huran, M. Kučera, A.P. Kobzev, and Š. Gaži

Properties study of silicon carbide thin films prepared by electron cyclotron resonance plasma technology

24014 J.F. Martinatti, L.V. Santos, N.C. Cruz, and E.C. Rangel

Hydrogenated amorphous carbon as protective coating for a forming tool

24015 P. Samyn, A. Airoudj, M.-P. Laborie, A.P. Mathew, and V. Roucoules

Plasma deposition of polymer composite films incorporating nanocellulose whiskers

24016 A. Hemberg, S. Konstantinidis, F. Renaux, J.P. Dauchot, and R. Snyders

Ion flux-film structure relationship during magnetron sputtering of $\mathrm{WO}_{3}$

24017 A. Bougharouat, A. Bellel, S. Sahli, Y. Ségui, and P. Raynaud

Plasma polymerization of TEOS for QCM-based VOC vapor sensing

24018 H. Tawidian, M. Mikikian, L. Couëdel, and T. Lecas

Plasma inhomogeneities near the electrodes of a capacitively-coupled radio-frequency discharge containing dust particles 
24019 J.-P. Borra, N. Jidenko, C. Dutouquet, O. Aguerre, J. Hou, and A. Weber (Invited paper)

Nano-droplet ejection and nucleation of materials submitted to non-thermal plasma filaments

24020 J. McKenna, J. Patel, S. Mitra, N. Soin, V. Švrček, P. Maguire, and D. Mariotti (Invited paper) Synthesis and surface engineering of nanomaterials by atmospheric-pressure microplasmas

24021 J. E. Punzón-Quijorna, V. Torres-Costa, A. Climent-Font, and M. Manso-Silván A multi-ion beam microanalysis approach for the characterization of plasma polymerized allylamine films

24022 R.C.C. Rangel, E.C. Rangel, R.M. Oliveira, M. Ueda, W.H. Schreiner, and N.C. Cruz Study of superficial properties of titanium treated by PIIID

24023 G. Da Ponte, E. Sardella, F. Fanelli, R. d'Agostino, and P. Favia

Trends in surface engineering of biomaterials: atmospheric pressure plasma deposition of coatings for biomedical applications

24024 A. Vesel, M. Mozetic, M. Jaganjac, L. Milkovic, A. Cipak, and N. Zarkovic Biocompatibility of oxygen-plasma-treated polystyrene substrates

24025 E.J. Jwa, Y.S. Mok, and S.B. Lee

Conversion of carbon oxides into methane in a nonthermal plasma-catalytic reactor

24026 B. Jaramillo-Sierra, A. Mercado-Cabrera, R. López-Callejas, J.A. López-Fernández, R. Peña-Eguiluz, S.R. Barocio, R. Valencia-Alvarado, B. Rodríguez-Méndez, A. Muñoz-Castro, and A. de la Piedad-Beneitez Phenol degradation in aqueous solution by a gas-liquid phase DBD reactor

24027 R. Ruffe, C. Martin, C. Pardanaud, G. Giacometti, P. Languille, P. Roubin, and B. Pégourié Plasma growth processes inside gaps of the castellated limiter of the Tore Supra tokamak 